\title{
On Knowing Humanity: Insights from Theology for Anthropology Edited by Eloise Meneses \& David Bronkema
}

\author{
Reviewed by Kenneth Nehrbass
}

Anthropology is defined by mutually held perspectives about human nature, and methods for studying cultures, rather than by a canonical body of knowledge. While anthropology has recently experienced a turn toward epistemological uncertainty, calling into question seminal theories in the discipline, many anthropologists remain committed to the hallmark perspectives of cultural relativism and a materialistic (rather than spiritual) ontology. Yet some are finding these perspectives to be unsatisfactory or even irrelevant. For instance, those interested in the anthropology of Christianity are beginning to challenge the rationalist view that religion only merits academic study insofar as it provides insight into social organization, politics, gender, material culture and so on.

On Knowing Humanity is a series of conceptual essays that offer Christian responses to these hegemonic perspectives of rationalism and relativism. As an interdisciplinary work, the authors move beyond the giants of anthropology to draw from the works of philosophers (Polanyi), theologians (Barth, Buber, TF Torrance, Volf) and sociologists (Berger), as well as from scripture.

What has theology to do with anthropology? As Eric Flett mentions in chapter 10 (referencing Karl Barth), if God became man, then theology and anthropology are natural conversation partners (209). The authors do not argue that secular anthropology is wrong in toto, but is incomplete without a foundation in

Kenneth Nehrbass is an assistant professor of Intercultural Studies at Biola University, and is a translation and anthropology consultant with the Seed Company and Summer Institute of Linguistics in the Pacific Area. He is the author of Christianity and Animism in Melanesia and Gods Image and Global Cultures. Author email: ken.nehrbass@biola.edu.
Christian theology in as much as it "lacks the explanatory power needed to elucidate its own subject material" (2). Or in some instances, the materialist ontology is so deeply held it has become sacrosanct. "The problem in anthropology is not the lack of an ontology, or even a kind of teleology... [but] that the content of these background beliefs is rarely if ever acknowledged" (92). Yet how can anthropologists genuinely understand the religious beliefs of the Other if they dismiss a priori a supernatural ontology? And if we are bearers of God's image, how can anthropologists who deny the supernatural ever expect to understand the nature of humankind? The authors of this volume ask anthropologists to cease privileging the ontology of rationalism (since it is, after all, a product of Western history) in order to explore ways that theology can provide further explanatory scope for the questions in anthropology (16).

To engage in this dialog between these two seemingly opposed academic disciplines, the authors suggest that foundational Christian concepts like humility, witness, mystery and calling can improve our ethnographic methods and can enrich the theories we produce about culture and human nature. Even though the authors re-interpret theological keywords like principalities, kenosis, witness and incarnation in light of anthropology, they avoid watering these terms down, and in fact deepen traditional Christian interpretations of these concepts.

For example, in noting that anthropologists are torn between the tension of subjectivity and objectivity, Brian Howell (chapter 2) suggests that the tension in theology between the transcendence and immanence of God can be illuminating: Christians believe that they can know in part, yet are resigned to the reality that deity remains somewhat mysterious. We are not agnostic about God (and do not need to be agnostic about humanity); we accept that our knowledge (of God and humanity) is perspectival, yet truth obtains. 
Or to take another example, anthropologists have recently come to understand the need for reflexivity, and even humility, when developing their anthropological theories. But they often lack a robust foundation for humility as a virtue. Kerry Dearborn (chapter 3) suggests that the biblical response to the "stranger" can serve as that foundation. Is the ethnographic Other a stranger? What can our understanding of the Good Samaritan teach us about how to relate to the stranger? Or how does Jesus' comment "I was a stranger, and you welcomed me" (Matt. 25:35) relate to building rapport in ethnographic fieldwork? And how does the Christian understanding of "witness" advance epistemology within the field of anthropology? As anthropologists are doubting whether we can truly know the Other at all-let alone generate timeless truths about humankind, Eloise Meneses (chapter 4) suggests that ethnography, like witnessing, is a form of "committed storytelling" (p. 98) where the testifier takes a risk, and tells these stories with an amount of reflexivity.

In a similar move toward meshing Christian concepts with anthropology, Lindy Backues (chapter 5) brilliantly connects the kenosis with a theory of cultural relativity: Christ gave up all power and prestige, humbly valuing all peoples; and our interaction with cultures demands the same posture toward the Other.

Not only do the authors tout virtues like humility and reflexivity, but as Joel Robbins observes in the epilogue, they employ these qualities throughout the volume-demonstrating how their own ethnography is enriched by such Christian concepts. For example, Stephen Ybarrola (chapter 9) demonstrates how the Christian idea of "calling" helps immigrants adjust to their host cultures. In fact, the volume would be richer if it included more applications of these ideals to specific ethnographic work. For example, David Bronkema (chapter 7) insightfully argues that community development is contingent upon peoples' views of the supernatural, and contends that anthropology should move beyond the "hegemonic constructivist paradigm" to "explore the implications of the power of the spiritual world" (171). But he concludes his essay immediately after making that point, rather than offering examples of how a belief in demons actually affects economic development in specific contexts. Or, to offer another example, Tito Paredes' essay (chapter 8) asks how taking Andean cosmology seriously can effect changes in the field of anthropology. But it is not clear how anthropologists would make use of Andean cosmology, especially since most anthropologists are unlikely to change their views of the supernatural. Likewise, what does it look like for a Christian to take Andean cosmology seriously? And Benjamin Hartley's historical research (chapter 6) on Agnes CL Donohugh meticulously traces the views of this champion of ethnography within Christian missions, but the chapter would be stronger if Hartley explained how Donohugh's approach to missionary ethnography can impact (or has impacted) the field of anthropology.

On Knowing Humanity, like its eponymous journal, advances the burgeoning discussion on the theology of culture. The authors maintain that as contingent beings, humans must turn not only to culture to find meaning in their lives (as Clifford Geertz expected) but ultimately to God whose image they bear.

New York: Routledge

2017 